Vol. 2 | No. 3 | 2021 | Hal. 238-243

\title{
EDUKASI PENCEGAHAN COVID-19 SESUAI PROTOKOL KESEHATAN MENGGUNAKAN MEDIA POSTER
}

\author{
Rahmawati*, Andrilia Safira, Lutfiah Rahmawaty, Sururul Fuadah, Amalia Rohmatul \\ Kamalia, Halimatus Sya'diyah, Jayanti Khusnul Kholifah, Nurul Farahdila Putri, \\ Ardiansyah, Neng Lina Sulastri, Fian Arifiona Faradila, Suriyanto, Retno Damayanti, \\ Khurrotun Nisa, Ahmad Fauzan \\ Fakultas Ekonomi dan Bisnis, Universitas Islam Malang \\ *korespondensi email: Rahmawati@unisma.ac.id
}

\begin{abstract}
ABSTRAK
Indonesia masih mengalami Pandemi Covid-19, beberapa upaya telah dilakukan oleh pemerintah, diantaranya menerapkan protokol kesehatan 5M dan menerapkan program vaksinasi. Tetapi masih banyak masyarakat yang belum mematuhi protokol kesehatan, salah satunya masih banyak ditemukan masyarakat yang tidak menggunakan masker. Melalui kegiatan KSM-Tematik 2021, mahasiswa tertarik memberikan solusi dengan mengedukasi masyarakat mengenai pencegahan Covid-19 melalui media poster di Desa Wonokerso, Kecamatan Pakisaji, Kabupaten Malang. Kegiatan dilakukan melalui tiga tahapan, diantaranya Persiapan, Pelaksanaan, dan Evaluasi. Desain Poster yang dibuat sebanyak empat desain dan dicetak dengan ukuran kertas Folio A4. Poster ditempelkan di beberapa lokasi Posko Satgas Covid-19. Setelah kegiatan penempelan poster dilakukan, mahasiswa mengamati perilaku masyarakat. Dengan demikian, edukasi pencegahan Covid-19 melalui media poster terhadap Masyarakat Wonokerso dinilai efektif.
\end{abstract}

Kata Kunci: edukasi; poster; covid-19

\section{PENDAHULUAN}

Indonesia sedang mengalami Bencana Nasional Pandemi Covid-19, sejak Maret 2020 kemarin, sudah banyak kasus masyarakat yang terjangkit virus ini hingga September 2021. Hal yang dapat dilakukan oleh pemerintah, diantaranya masyarakat dihimbau untuk selalu mematuhi protokol 5M (Memakai masker, Menjaga Jarak, Mencuci Tangan, Menghindari Kerumunan, dan Membatasi Mobilitas) dan baru-baru ini pemerintah akan memperpanjang kebijakan PPKM (Pemberlakuan Pembatasan Kegiatan Masyarakat untuk di wilayah Jawa-Bali mulai 7 September 2021 sampai 13 September 2021.

Dilansir dari Kementerian Kesehatan RI, dalam rangka menangani virus ini, Pemerintah membuat Program Vaksinasi Covid-19 sejak Januari 2021. Orang yang pertama kali menerima suntikan vaksin adalah Presiden Joko Widodo dan diikuti dengan sejumlah pejabat, tokoh agama, organisasi profesi, dan masyarakat yang mengikuti vaksinasi (Kemenkes, 2021). Pemberian vaksin berfungsi untuk mencegah penularan dan mengurangi gejala yang dialami apabila terpapar oleh Virus Covid-19. Meskipun vaksin sudah diberikan, kita tetap wajib mematuhi protokol kesehatan yang ada.

Berdasarkan hasil pengamatan, salah satu permasalahan yang ada di Masyarakat Desa Wonokerso, Kecamatan Pakisaji, Kabupaten Malang adalah kurangnya kesadaran masyarakat terhadap protokol kesehatan diantaranya, memakai masker dan menjaga jarak. Masyarakat kurang 
memiliki pemahaman mengenai seberapa rentan akan terpapar Virus Covid-19. Masih banyak masyarakat yang masih lalai dalam memperhatikan protokol kesehatan terlebih di Era New Normal ini, sehingga diperlukan Sosialisasi dan Edukasi untuk meningkatkan pemahaman masyarakat pentingnya memperhatikan protokol kesehatan dalam melaksanakan aktivitas (Rahmawati et al. 2020).

Berdasarkan permasalahan yang muncul, kegiatan KSM-Tematik 2021 Universitas Islam Malang dilakukan dengan program kerja adalah melakukan edukasi pencegahan Covid-19 melalui media poster terhadap masyarakat Desa Wonokerso, Kecamatan Pakisaji, Kabupaten Malang. Media adalah sesuatu yang digunakan untuk merangsang pikiran, perasaan, perhatian, minat peserta didik sedemikian rupa sehingga proses belajar terjadi, salah satu media yang dapat dimanfaatkan untuk meningkatkan kognitif peserta didik adalah media visualisasi (Yusandika et al., 2018).

Poster merupakan pesan singkat dalam bentuk gambar dengan tujuan untuk mempengaruhi sesorang agar tertarik pada sesuatu, atau mempengaruhi agar seseorang bertindak akan sesuatu hal (Sumartono \& Astuti, H, 2018; Masruroh \& Hayati, 2021). Poster merupakan media gambar yang digunakan untuk memudahkan proses penyampaian informasi, saran, atau ide tertentu sehingga dapat merangsang keinginan orang yang melihatnya untuk melaksanakan isi pesan tersebut (Yusandika et al., 2018). Dalam melakukan edukasi pencegahan Covid-19, diharapkan dapat memberikan masukan informasi bagi Masyarakat Wonokerso dan meningkatkan kesadaran diri serta mendisiplinkan diri akan pentingnya mematuhi protokol kesehatan.

\section{METODE}

Metode Pelaksaan yang digunakan terdiri dari Tiga tahapan diantaranya, Persiapan, Pelaksanaan, dan Evaluasi. Tahapan Persiapan meliputi Mengidentifikasi permasalahan di masyarakat, Survei Lokasi dan Tempat untuk menempelkan poster, dan Mempersiapkan bahan untuk isi poster. Tahapan Pelaksanaan meliputi Penempelan poster edukasi di lokasi dan tempat yang sudah ditentukan. Dalam pelaksanaannya, desain poster akan ditempelkan di beberapa lokasi posko satgas Covid-19 Desa Wonokerso. Tahapan Evaluasi dilakukan setelah poster sudah ditempelkan dengan cara melakukan observasi terhadap Masyarakat, untuk mengetahui seberapa efektif penggunaan media poster sebagai edukasi pencegahan Covid-19.

\section{HASIL DAN PEMBAHASAN}

Pemerintah berupaya menangani Virus Covid-19, salah satunya dengan menerapkan protokol kesehatan yang awalnya 3M berkembang menjadi 5M. Dilansir dari Halodoc, Protokol Kesehatan 5M yang diterapkan di Indonesia diantaranya, Mencuci Tangan, Memakai Masker, Menjaga Jarak, Menjauhi Kerumunan, dan Mengurangi Mobilitas (Halodoc, 2021). Mencuci tangan berguna untuk membunuh virus dan kuman disarankan menggunakan sabun dan air atau pembersih tangan yang mengandung alkohol dengan kadar 60\%. Memakai Masker menjadi hal yang wajib digunakan masyarakat saat beraktivitas, sekarang masyarakat dihimbau untuk menggunakan double masker atau bisa menggunakan masker KN94 atau KN95. Menjaga Jarak minimal 1 meter dengan orang lain untuk menghindari terkena droplet dari orang yang bicara, batuk, atau bersin, serta menghindari kerumunan, keramaian, dan berdesakan (Kemenkes, 2020). Menjauhi Kerumunan diperlukan untuk mengurangi potensi tertular Virus Covid-19. Seseorang yang sakit dan lansia diharapkan untuk menjauhi kerumunan atau tetap berada dirumah karena rawan tertular virus. Mengurangi Mobilitas juga penting dilakukan, saat pandemi lebih baik tetap berada di rumah dang mengurangi aktivitas di luar rumah. Oleh karena itu, Mahasiswa KSM-Tematik 2021 Universitas Islam Malang memutuskan untuk membuat beberapa desain posterKSM-Tematik 2021 Universitas Islam Malang memutuskan untuk membuat beberapa desain poster. 


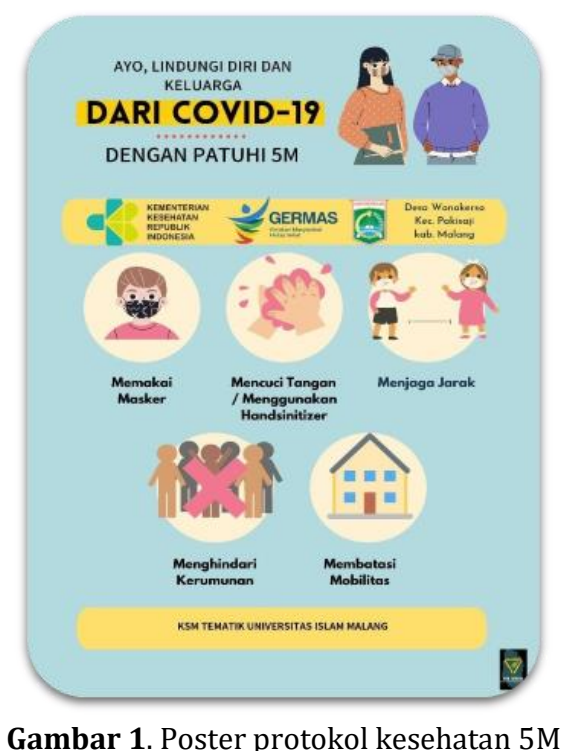

Poster selanjutnya berisi tentang cara menggunakan masker dengan benar, berdasarkan hasil pengamatan Masyarakat Wonokerso belum menggunakan masker dengan tepat. Masih ada yang meletakkan masker di bawah dagu, meskipun saat berbicara dengan lawan bicara. Oleh karena itu, penulis ingin membuat poster mengenai informasi penggunaan masker yang benar. Desain poster dapat dilihat pada Gambar 2.

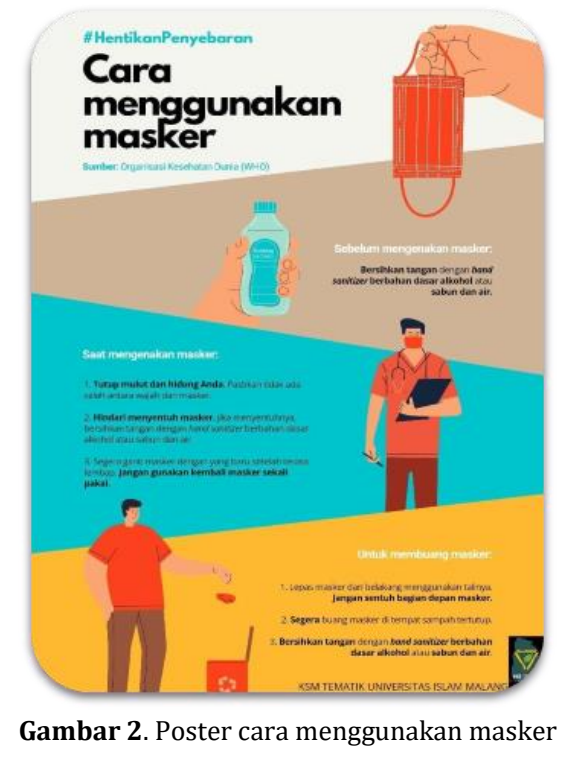

Poster berikutnya mengenai informasi untuk menjaga jarak. Dapat dilihat bahwa Masyarakat masih melakukan kegiatan di luar rumah yang menyebabkan kurangnya kesadaran diri untuk menjaga jarak satu sama lain. Desain poster dapat dilihat pada Gambar 3. 


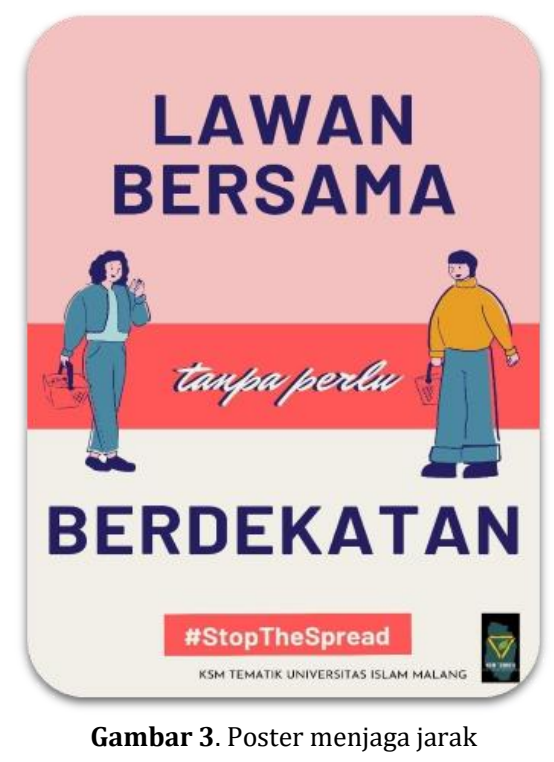

Poster terakhir berisi tentang informasi cara batuk dan bersin diletakkan di lengan. Bertujuan agar bakteri dan virus tidak menyebar ke udara atau mengenai orang lain. Desain poster dapat dilihat pada Gambar 4.

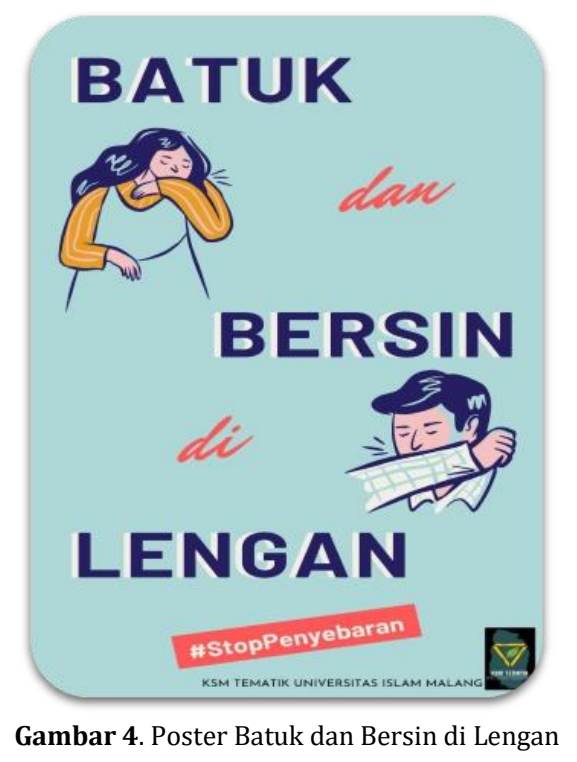

Desain Poster menggunakan aplikasi Canva dan dicetak menggunakan kertas Folio A4. Setelah poster dicetak, poster ditempelkan di beberapa lokasi posko satgas Covid-19 Desa Wonokerso. Penempelan Poster dapat dilihat pada Gambar 5.

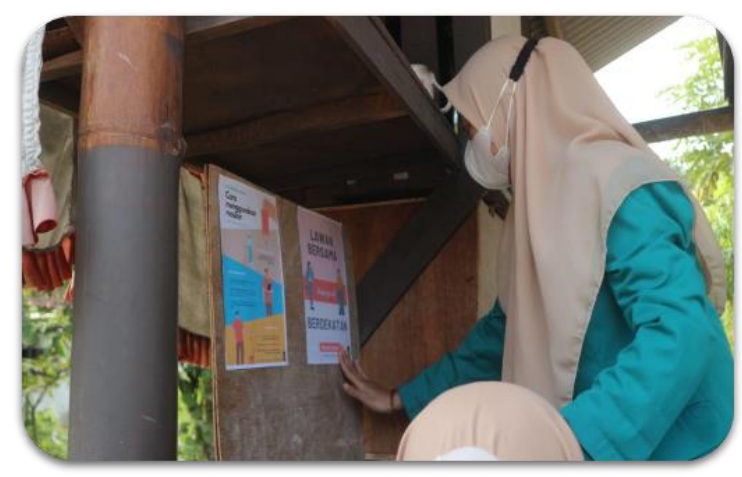

Gambar 5. Penempelan poster 
Pembahasan pada kegiatan edukasi poster Covid-19 ini bahwa media poster dapat dijadikan sebagai media informasi bagi masyarakat Desa Wonokerso, Kecamatan Pakisaji, Kabupaten Malang. Penggunaan media poster sebagai edukasi juga terbilang efektif karena dapat menarik perhatian pembacanya dan dapat meninggalkan kesan, meskipun dibaca sambil berlalu. Poster memiliki beberapa kelebihan dapat mempermudah dan mempercepat pembaca terhadap pesan yang disajikan, dapat dilengkapi dengan warna-warna yang dapat menarik perhatian pembaca, bentuknya sederhana tanpa memerlukan peralatan khusus dan mudah untuk penempatannya dan membuatnya pun mudah dan harganya murah (Harsismanto et al., 2019). Disamping itu, poster juga memiliki kelebihan sebagai media komunikasi visual karena memuat informasi secara singkat, padat dan jelas, serta dapat diproduksi secara masal (Karimun, M. \& Syafii, 2021). Poster juga memiliki kelemahan yaitu media ini tetap, diperlukan dalam keahlian bahasa dan ilustrasi dalam membuat poster, dapat menimbulkan salah tafsir, dari kata/kata simbol yang singkat, membutuhkan proses penyusunan dan penyebaran yang komplek dan membutuhkan waktu yang relatif lama dan jenis bahan yang digunakan biasanya mudah sobek, artinya gangguan mekanis tinggi, sehingga informasi yang diterima tidak lengkap (Yusandika et al., 2018). Membuat poster juga memerlukan keterampilan khusus dalam pembuatannya dan diperlukan kemampuan membaca untuk memahami isi poster (Sumartono \& Astuti, H, 2018).

Meskipun demikian, penggunaan poster sebagai media edukasi tetap membawa pengaruh yang positif bagi Masyarakat Desa Wonokerso, Hal ini dapat diketahui dari hasil pengamatan setelah kegiatan penempelan poster edukasi Covid-19 dilakukan. Masyarakat Desa Wonokerso sudah banyak yang memakai masker dengan benar saat melakukan aktivitas di luar rumah. Memakai Masker sudah seperti barang yang wajib dibawa dan dipakai di saat Era New Normal. Hasil Penelitian Terdahulu juga menunjukkan bahwa pemilihan media poster untuk menyampaikan pesan kepada masyarakat dinilai cukup efektif (Nurhadi et al., 2020). Meskipun demikian, penggunaan poster sebagai media edukasi tetap membawa pengaruh yang positif bagi Masyarakat Desa Wonokerso. Hal ini dapat diketahui dari hasil pengamatan setelah kegiatan penempelan poster edukasi Covid-19 dilakukan. Masyarakat Desa Wonokerso sudah banyak yang memakai masker dengan benar saat melakukan aktivitas di luar rumah. Memakai Masker sudah seperti barang yang wajib dibawa dan dipakai di saat Era New Normal.

\section{KESIMPULAN}

Pemerintah telah berupaya menangani Virus Covid-19 dengan sebaik mungkin, salah satunya dengan mengeluarkan kebijakan untuk selalu mematuhi Protokol Kesehatan 5M yang telah dibuat untuk seluruh Indonesia. Sebagai Warga Indonesia hendaknya juga turut ikut serta mematuhi peraturan yang telah dibuat oleh Pemerintah. Salah satunya dengan mengedukasi Masyarakat Desa Wonokerso, Kecamatan Pakisaji, Kabupaten Malang melalui media poster yang berisi informasi mengenai Pencegahan Virus Covid-19. Media Poster digunakan karena mudah dipahami dan dapat menarik perhatian masyarakat. Dengan demikian, edukasi pencegahan Covid-19 melalui media poster terhadap Masyarakat Wonokerso dinilai efektif. Mahasiswa KSM-Tematik 2021 Universitas Islam Malang berharap Masyarakat Wonokerso dapat mematuhi protokol kesehatan 5M yang dikeluarkan oleh pemerintah dan diberikan sosialisasi mengenai pencegahan Virus Covid-19.

\section{UCAPAN TERIMA KASIH}

Terima kasih kepada Tuhan Yang Maha Esa yang telah memberikan rahmat dan hidayah-Nya serta memberikan kesehatan sampai saat ini demi menjalankan KSM (Kandidat Sarjana Mengabdi) Tematik di Desa Wonokerso, Kecamatan Pakisaji, Kabupaten Malang. Terima kasih kepada orang tua kami dan terima kasih kepada pihak Universitas Islam Malang yang telah mendukung penuh pelaksanaan KSM-Tematik tahun 2021. Ibu Dr. Nour Athiroh AS, S.Si., M.Kes. selaku Ketua Lembaga Penelitian Pengabdian kepada Masyarakat (LPPM).

\section{DAFTAR RUJUKAN}

Halodoc. (2021). Mengenal Protokol Kesehatan 5M untuk Cegah COVID-19. Diakses pada tanggal 
https://www.halodoc.com/artikel/mengenal-protokol-kesehatan-5m-untuk-cegahcovid-19

Harsismanto, J., Oktavidiati, E., \& Astuti, D. (2019). Pengaruh pendidikan kesehatan media video dan poster terhadap pengetahuan dan sikap anak dalam pencegahan penyakit diare. Jurnal Kesmas Asclepius, 1(1), 75-85.

Karimun, M., \& Syafii, S. (2021). DESAIN POSTER DIGITAL KARYA SISWA KELAS X MIPA 2 SMA NEGERI 3 DEMAK. Eduarts: Jurnal Pendidikan Seni, 10(2), 65-75.

Kemenkes RI. (2020). Pedoman Pencegahan dan Pengendalian Coronavirus Disease (COVID19). Jakarta: Kemenkes RI \& Dirjen Pencegahan dan Pengendalian Penyakit.

Kemenkes RI. (2021). Protokol Kesehatan Bagi Masyarakat di Tempat dan Fasilitas Umum Dalam Rangka Pencegahan COVID-1. Jakarta: Kemenkes RI \& Dirjen Pencegahan dan Pengendalian Penyakit.

Masruroh, \& Hayati, N. (2021). Media poster sebagai sarana edukasi masyarakat dalam upaya pencegahan covid-19. Jurnal Inovasi Hasil Pengabdian Masyarakat (JIPEMAS), 4(36), 169-176. https://doi.org/10.33474/jipemas.v4i2.9207

Nurhadi, Z. F., Parentza, H., Munandar, A., Rachman, D., \& Muldan, Y. D. (2021). Strategi Komunikasi Dan Edukasi Pencegahan Covid-19 Melalui Media Poster. ABDIMAS: Jurnal Pengabdian Masyarakat, 4(1), 537-543.

Rahmawati, R., Rahmah, S. F., Mahda, D. R., Purwati, T., Utomo, B. S., \& Nasution, A. M. (2021, February). Edukasi Protokol Kesehatan dalam Menjalankan New Normal di Masa Pandemik Melalui Media Poster. In Prosiding Seminar Nasional Pengabdian Masyarakat LPPM UMJ (Vol. 1, No. 1).

Sumartono, S., \& Astuti, H. (2018). Penggunaan Poster Sebagai Media Komunikasi Kesehatan. KOMUNIKOLOGI: Jurnal Ilmiah Ilmu Komunikasi, 15(1).

Yusandika, A. D., Istihana, I., \& Susilawati, E. (2018). Pengembangan Media Poster Sebagai Suplemen Pembelajaran Fisika Materi Tata Surya. Indonesian Journal of Science and Mathematics Education, 1(3), 187-1 